\title{
Treatment of mastitis during lactation
}

Pyörälä S

University of Helsinki, Faculty of Veterinary Medicine, Department of Production Animal Medicine, Pohjoinen Pikatie $800 \mathrm{Fl}-04920$ Saarentaus, Finland

Tel: +358919140533

Fax: +358 196851181

E-mail: satu.pyorala@helsinki.fi

\section{ABSTRACT}

Treatment of mastitis should be based on bacteriological diagnosis and take national and international guidelines on prudent use of antimicrobials into account. In acute mastitis, where bacteriological diagnosis is not available, treatment should be initiated based on herd data and personal experience. Rapid bacteriological diagnosis would facilitate the proper selection of the antimicrobial. Treating subclinical mastitis with antimicrobials during lactation is seldom economical, because of high treatment costs and generally poor efficacy. All mastitis treatment should be evidence-based, i.e., the efficacy of each product and treatment length should be demonstrated by scientific studies. Use of on-farm written protocols for mastitis treatment promotes a judicious use of antimicrobials and reduces the use of antimicrobials.

KEYWORDS: antibiotic; antimicrobial; bovine; intramammary; lactation; mastitis; systemic; therapy; treatment

Irish Veterinary Journal volume 62 Supplement 40-44 2009

\section{INTRODUCTION}

Intramammary infection (mastitis) is the most common reason for the use of antimicrobials in dairy cows (Mitchell et al. 1998; Grave et al. 1999). Antimicrobials have been used to treat mastitis for more than fifty years, but consensus about the most efficient, safe, and economical treatment is still lacking. The concept of evidence-based medicine has been introduced to veterinary medicine (Cockcroft and Holmes 2003) and should apply also to treatment of mastitis. The impact on public health should be taken into account as dairy cows produce milk for consumption (OIE 2008). The aim of this article is to review current treatments of mastitis during lactation and seek for evidence-based, best practice treatment recommendations for bovine mastitis.

\section{PHARMACOKINETIC AND PHARMACODYNAMIC CONSIDERATIONS}

The bovine mammary gland is a difficult target for antimicrobial treatment. Penetration of substances into milk when administered parenterally or absorption and distribution throughout the udder when infused intramammarily (IMM) depends on their pharmacokinetic characteristics. These are lipid solubility, degree of ionization, extent of binding to serum and udder proteins, and the type of vehicle. Antimicrobial treatment of dairy cows creates residues into milk, and residue avoidance is an important aspect of mastitis treatment (Wagner and Erskine 2006).

Pharmacodynamics of the antimicrobial is another aspect which should be considered. Milk should not interfere with antimicrobial activity. The activity of macrolides, tetracyclines and trimethoprim-sulphonamides has been shown to be reduced in milk (Louhi et al. 1992; Fang and Pyörälä 1996). Selecting a substance with a low minimum inhibitory concentraton (MIC) value for the target pathogen is preferable, particularly when the antimicrobial is administered systemically. The antimicrobial should have bactericidal rather than bacteriostatic action, because phagocytosis is impaired in the mammary gland (Kehrli and Harp 2001).

Antimicrobial susceptibility determined in vitro has been considered as a prerequisite for treatment. However, activity in vitro does not guarantee efficacy in vivo when 
treating bovine mastitis. Antimicrobial resistance amongst mastitis pathogens has not yet emerged as a clinically relevant issue, but geographical regions may differ in this respect. The biggest problem is the widespread resistance of staphylococci, particularly Staphylococcus aureus, to penicillin G (Pitkälä et al. 2004; Olsen et al. 2006; Hendriksen et al. 2008). Cure rates for mastitis caused by penicillin-resistant strains of $S$. aureus seem to be inferior to those of mastitis due to penicillin-susceptible strains (Ziv and Storper 1985; Pyörälä and Pyörälä 1998; Sol et al. 2000; Taponen et al. 2003). It is not known if this is due to pharmacologic problems of the drugs used, or virulence factors possibly linked to $\beta$-lactamase gene of the resistant isolates (Haveri et al. 2005). Using an in vitro $\beta$-lactamase test for determining resistance to penicillin $G$ of staphylococci before treatment is recommended (Olsen et al. 2006).

Coagulase-negative staphylococci tend to be more resistant than S. aureus and easily develop multiresistance (Pitkälä et al. 2004; Sawant et al. 2009). Mastitis causing streptococci have remained susceptible to penicillin G, but emerging resistance to macrolides and lincosamides has been detected (Pitkälä et al. 2004; Loch et al. 2005). Antimicrobial susceptibility of coliform bacteria varies but normally is not a limiting factor for therapy (Lehtolainen et al. 2003; FINRES-Vet 2007; Wagner and Erskine 2006).

\section{INTRAMAMMARY OR SYSTEMIC ADMINISTRATION?}

An important question regarding the treatment of mastitis is whether the antimicrobial should accumulate in the milk or in the udder tissue (Erskine 2003). The target site may depend on the causative agent: streptococci are known to remain in the milk compartment, but $S$. aureus penetrates udder tissue and causes deep infection (Table 1). The most common route of administration of antimicrobials in mastitis is the IMM route. The advantages of this route are high concentrations of the substance achieved in the milk and low consumption of the antimicrobial as the drug is directly infused into the diseased quarter. For example, concentration of penicillin $\mathrm{G}$ in milk after IMM administration is $100-1000$ times as high as the concentration after systemic (parenteral) administration (Franklin et al. 1984, 1986; Ziv and Storper 1985; Moretain and Boisseau 1989). A disadvantage of the

Table 1: Where to target antimicrobial therapy in clinical mastitis due to different pathogens (Erskine 2003)

\begin{tabular}{|l|l|l|l|}
\hline & Milk/ducts & $\begin{array}{l}\text { Udder } \\
\text { tissue }\end{array}$ & Cow \\
\hline Streptococcus agalactiae & +++ & -- & -. \\
\hline Other streptococci & +++ & + & $\ldots$ \\
\hline Staphylococcus aureus & + & +++ &.-- \\
\hline Coagulase-negative staphylococci & +++ &.-- & -- \\
\hline $\begin{array}{l}\text { Arcanobacterium pyogenes } \\
\text { (summer mastitis) }\end{array}$ & -- & ++ & +++ \\
\hline Coliforms & + & & \\
\hline
\end{tabular}

IMM administration is uneven distribution throughout the udder (Ullberg et al. 1958; Ehinger and Kietzmann 2000a, $2000 \mathrm{~b}$ ) and the risk of infecting the quarter when infusing the product via the teat canal. Efficacy of IMM treatment varies according to the causative pathogen, with the best therapeutic response being shown for mastitis caused by streptococci, coagulase-negative staphylococci, and Corynebacterium spp..

The systemic route of administration has been suggested to be more efficient than IMM for the treatment of clinical mastitis as antimicrobials theoretically have better penetration of the udder tissue by this route (Ziv 1980; Erskine 2003). However, it is difficult to attain and maintain therapeutic concentrations in milk or udder tissue following systemic administration. Very few substances have optimal pharmacokinetic and pharmacodynamic characteristics for systemic mastitis treatment. With many commonly used broad-spectrum antimicrobials such as oxytetracycline, trimethoprim-sulphonamide and ceftiofur, it is difficult to produce and maintain therapeutic concentrations in the milk (Erskine et al. 1995; Kaartinen et al. 1999). They have been tested for systemic treatment and prevention of mastitis with poor efficacy (Erskine and Barlett 1996; Kaartinen et al. 1999; Duenas et al. 2001; Lents et al. 2002). Macrolides would have ideal pharmacokinetics (Franklin et al. 1986; Sanders et al. 1992), but clinical studies have failed to demonstrate efficacy when used for the systemic treatment of clinical mastitis (Pyörälä and Pyörälä 1998; Owens et al. 1999). In streptococcal mastitis, spiramycin and tylosin have shown reasonable efficacy (Pyörälä and Pyörälä 1998; McDougall et al. 2007). One additional problem for the bovine practitioner is that the recommended dosage for many antibiotic preparations for adult cattle may be too low when pharmacological aspects are considered, but residue studies have been carried out using the approved dosages. Repeated intramuscular injections of large volumes of antibiotics can be irritating and cannot be recommended from the animal welfare point of view (Pyörälä et al. 1994b; Kaartinen et al. 1999).

One substance used for systemic treatment is penicillin $\mathrm{G}$, which as a weak acid penetrates poorly into the mammary gland, however, due to the very low MIC values of susceptible organisms, therapeutic concentrations can be achieved in milk (Franklin et al. 1984, 1986; Ziv and Storper 1985). Penethamate is a more liphophilic penicillin $\mathrm{G}$ formulation and diffuses better than penicillin $\mathrm{G}$ procaine into milk (Ziv and Storper 1985). The efficacy of systemic treatment with penicillin $\mathrm{G}$ or penethamate has been shown in clinical trials (Jarp et al. 1989; Waage 1997; Pyörälä and Pyörälä 1998; McDougall et al. 2007). Combinations of penicillin and aminoglycosides should not be used, as there is no scientific evidence demonstrating a better efficacy for the combination (Taponen et al. 2002) and aminoglycosides are known to produce long-lasting residues (Jones and Ward 1990; Whittem and Hanlon 1997).

The only type of mastitis where systemic treatment would be clearly advantageous may be mastitis caused by $S$. 
aureus (Taponen et al. 2003; Barkema et al. 2006). In severe mastitis due to coliform bacteria, parenteral administration of antimicrobials has been suggested to combat bacteraemia (Wenz et al. 2001). The general benefit of antimicrobial treatment in coliform mastitis has been questioned (Jones et al. 1990; Pyörälä et al. 1994a), but systemic antimicrobial treatment is recommended in cases of severe Escherichia coli mastitis with heavy bacterial growth in the udder. Fluroquinolones and cefquinome have shown efficacy in experimental trials (Shpigel et al. 1997; Dosogne et al. 2002; Rantala et al. 2002; Poutrel et al. 2008) and ceftiofur in a clinical field trial (Erskine et al. 2002). There is no evidence that administering bactericidal antimicrobials to cows with severe coliform mastitis causes the release of massive amounts of endotoxin (Dosogne et al. 2002). Finally, the antimicrobial used for systemic treatment of mastitis must be approved for dairy cattle. The availability of substances on the market differs between countries. For example, penicillin $\mathrm{G}$ procaine or fluoroquinolones are not approved for dairy cattle in the United States.

\section{TREATMENT OF CLINICAL MASTITIS IN PRACTICE}

Treatment of mastitis should be targeted towards the causative bacteria whenever possible, but in acute situations, treatment is initiated based on herd data and personal experience. Rapid or on-farm bacteriological diagnosis would facilitate the selection of the most appropriate antimicrobial. Treatment protocols and drug selection for each farm should be made by veterinarians familiar with the farm (Sawant et al. 2005; Wagner and Erskine 2006). The use of on-farm written protocols for mastitis treatment can promote judicious use of antimicrobials (Raymond et al. 2006; Passantino 2007). Therapeutic response of the cows can be monitored using individual somatic cell count data if available, or using the California Mastitis Test, and with bacteriological samples in herds with contagious mastitis.

In general, the use of narrow-spectrum antimicrobials is preferable (Table 2). Prudent use guidelines have been developed which also include antimicrobial treatment of mastitis (Anon 2003; Passantino 2007). First choice antimicrobials for treating mastitis caused by streptococci and penicillin-susceptible staphylococci are $\beta$-lactam antimicrobials, particularly penicillin G. Broad-spectrum antimicrobials such as third or fourth generation cephalosporins should not be used as first alternatives for mastitis, as they may increase emergence of broadspectrum $\beta$-lactam resistance. Systemic treatment is recommended in clinical mastitis due to $S$. aureus and in severe cases of coliform mastitis, preferably in combination with IMM treatment (Barkema et al. 2006). Too short a duration of standard treatment is probably an important reason for poor cure rates in mastitis therapy. A longer treatment improves cure rates, and duration of treatment should generally be extended in mastitis caused by $S$. aureus and Streptococcus uberis (Pyörälä and Pyörälä 1998; Oliver et al. 2004; Deluyker et al. 2005). Clinical mastitis should be treated for at least three days; this recommended treatment duration is longer than label treatments in many countries. All mastitis treatment should be evidence based i.e., the efficacy of each product and treatment length should be demonstrated by scientific studies (Cockcroft and Holmes 2003).

\section{SUBCLINICAL MASTITIS}

Treating subclinical mastitis with antimicrobials is generally not economical during lactation because of high treatment costs and poor efficacy. In a study with a large number of subclinical mastitis cases (Wilson et al. 1999), the overall bacteriological cure rate for antimicrobial treatment was $75 \%$ and that for no treatment $68 \%$. The marginal benefit applied for streptococcal mastitis only; in mastitis due to $S$. aureus, antimicrobials were equal to no treatment. Treatment of subclinical mastitis will not affect the incidence of mastitis in the herd unless other preventive measures are taken. Studies on treating cows based on high somatic cell counts have generally shown that no effect on milk production has been achieved (McDermott et al. 1983; Shephard et al. 2000, Hallén Sandgren et al. 2008) In herd problems caused by very contagious bacteria such as S. aureus or Streptococcus agalactiae treatment of subclinical mastitis is advised (Wagner and Erskine 2006).

Table 2: Suggestions for antimicrobial treatment of clinical mastitis due to different pathogens. The availability of substance on the market mentioned in the table may differ between countries

\begin{tabular}{|c|c|c|c|c|}
\hline Micro-organism & Species & Drug of choice & Alternative & Comments \\
\hline Streptococci & $\begin{array}{l}\text { Streptococcus agalactiae } \\
\text { Streptococcus dysgalactiae } \\
\text { Streptococcus uberis } \\
\text { Enterococci }\end{array}$ & $\begin{array}{l}\text { Penicillin G } \\
\text { According to } \\
\text { susceptibility testing }\end{array}$ & & $\begin{array}{l}\text { IMM treatment preferable. } \\
\text { Prognosis for bacteriological cure is poor }\end{array}$ \\
\hline Staphylococci & $\begin{array}{l}\text { Staphylococcus aureus } \\
\text { Coagulase negative staphylococci } \\
\text { ß-lactamase -ve } \\
\text { Staphylococcus aureus } \\
\text { Coagulase negative staphylococci } \\
\text { ß-lactamase +ve }\end{array}$ & $\begin{array}{l}\text { Penicillin G } \\
\text { No antimicrobials }\end{array}$ & $\begin{array}{l}\text { Cloxacillin Macrolides } \\
\text { Lincosamides }\end{array}$ & $\begin{array}{l}\text { Combination treatment in S. aureus mastitis } \\
\text { IMM and/or systemic treatment depending on the drug } \\
\text { used. Prognosis for } S \text {. aureus mastitis is poor. Cloxacillin } \\
\text { may select for methicillin-resistant }\end{array}$ \\
\hline Coliforms & $\begin{array}{l}\text { Escherichia coli } \\
\text { Klebsiella spp. }\end{array}$ & No antimicrobials & $\begin{array}{l}\text { Fluoroquinolones } \\
\text { Cephalosporins }\end{array}$ & $\begin{array}{l}\text { Antimicrobials necessary in serious cases and during } \\
\text { puerperal period }\end{array}$ \\
\hline
\end{tabular}




\section{REFERENCES}

Anonymous (2003) Use of antimicrobial agents in animals. Report of the working group on antimicrobial agents. Ministry of Agriculture and Forestry in Finland. MAFF Publications 9. [Online] Helsinki, MAFF. Available from: $<$ http://wwwb.mmm.fi/julkaisut/ tyoryhmamuistiot/2003/tr2003_9.pdf> [Accessed February 20 2006].

Barkema H, Schukken YH and Zadoks RN (2006) Invited review: the role of cow, pathogen, and treatment regimen in the therapeutic success of bovine Staphylococcus aureus mastitis. J Dairy Sci 89, 1877-1895.

Cockcroft P, Holmes M (2003) Evidence-based veterinary medicine. (1st edn), Oxford UK, Blackwell Publishing.

Deluyker HA, Van Oye SN and Boucher JF (2005) Factors affecting cure and somatic cell count after pirlimycin treatment of subclinical mastitis in lactating cows. J Dairy Sci 88, 604-614.

Dosogne H, Meyer E, Sturk A et al. (2002) Effect of enrofloxacin treatment on plasma endotoxin during bovine Escherichia coli mastitis. Inflamm Res 51, 201205.

Duenas MI, Paape MJ, Wettemann RP et al. (2001) Incidence of mastitis in beef cows after intramuscular administration of oxytetracycline. J Anim Sci 79, 19962005.

Ehinger AM, Kietzmann M (2000a) Tissue distribution of oxacillin and ampicillin in the isolated perfused bovine udder. J Vet Med A 47, 157-168.

Ehinger AM, Kietzmann M (2000b) Tissue distribution of benzylpenicillin after intramammary administration in the isolated perfused bovine udder. J vet Pharm Therap 23, 303-310.

Erskine RJ (2003) Antibacterial therapy of clinical mastitis part I. Drug selection. Part II Administration. North Am Vet Conf, Proc 13-16.

Erskine RJ, Barlett PC (1996) Intramuscular administration of ceftiofur sodium versus intramammary infusion of penicillin/novobiocin for treatment of Streptococcus agalactiae mastitis in dairy cows. J Am Vet Med Assoc 208, 258-260.

Erskine RJ, Barlett PC, VanLente JL et al. (2002) Efficacy of systemic ceftiofur for severe clinical mastitis in dairy cattle. J Dairy Sci 85, 2571-2575.

Erskine RJ, Wilson RC, Tyler JW et al. (1995) Ceftiofur distribution in serum and milk from clinically normal cows and cows with experimental Escherichia coli-induced mastitis. Am J Vet Res 56, 481-486.

Fang W, Pyörälä S (1996) Mastitis causing Escherichia coli: serum sensitivity and susceptibility to selected antibacterials in milk. J Dairy Sci 79, 76-82.

FINRES-Vet 2005-2006 (2007) Finnish veterinary antimicrobial resistance monitoring and comsumption of antimicrobial agents. Finnish Food Safety Authority Evira [Internet] Helsinki, Multiprint Available from:http://www. palvelu.fi/evi/files/55_519_523.pdf [Accessed January 31 2009].

Franklin A, Holmberg O, Horn af Rantzien M et al. (1984) Effect of procaine benzylpenicillin alone or in combination with dihydrostreptomycin on udder pathogens in vitro and in experimentally infected bovine udders. Am J Vet Res
45, 1398-1402.

Franklin A, Horn af Rantzien M, Obel N et al. (1986)

Concentrations of penicillin, streptomycin, and spiramycin in bovine udder tissue liquids. Am J Vet Res 47, 804807.

Grave T, Greko C et al. (1999) The usage of veterinary antibacterial drugs for mastitis in cattle in Norway and Sweden during 1990-1997. Prev Vet Med 42, 45-55.

Hallén Sandgren C, Persson Waller K, Emanuelson U (2008) Therapeutic effects of systemic or intramammary antimicrobial treatment of bovine subclinical mastitis during lactation. Vet J 175, 108-117.

Haveri M, Roslöf A, Rantala L et al. (2005) Virulence genes in bovine Staphylococcus aureus mastitis of different clinical characteristics and outcome. J Appl Microb 103, 993-1000.

Hendriksen RS, Mevius DJ, Schroeter A et al. (2008) Prevalence of antimicrobial resistance among bacterial pathogens isolated from cattle in different European countries: 2002-2004. Acta Vet Scand 50, 28 [Online] Available from: www.actavetscand.com/content/50/1/28

Jarp J, Bugge HP and Larsen S (1989) Clinical trial of three therapeutic regimens for bovine mastitis. Vet Rec 124, 630-634.

Jones GF, Ward GE (1990) Evaluation of systemic administration of gentamicin for treatment of coliform mastitis in cows. J Am Vet Med Assoc 197, 731-735.

Kaartinen L, Löhönen K, Wiese B et al. (1999) Pharmacokinetics of sulphadiazine-trimethoprim in lactating dairy cows. Acta vet Scand 40, 271-278.

Kehrli M, Harp J (2001) Immunity in the mammary gland. Vet Clinics North Am - Food Animal Practice 17, 495-516.

Lehtolainen T, Shpigel N, Pohjanvirta T et al. (2003) In vitro antimicrobial susceptibility of Escherichia coli isolates originating from clinical mastitis in Finland and Israel. J Dairy Sci 86, 3927-3932.

Lents CA, Wettemann RP, Paape MJ et al (2002) Efficacy of intramuscular treatment of beef cows with oxytetracycline to reduce mastitis and to increase calf growth. J Anim Sci 80, 1405-1412.

Loch IM, Glenn K and Zadoks RN (2005) Macrolide and lincosamide resistance genes of environmental streptococci from bovine milk. Vet Microb 111, 133-138.

Louhi M, Inkinen K, Myllys V et al. (1992) Relevance of sensitivity testings (MIC) of $S$. aureus to predict the antibacterial action in milk. J Vet Med B 39, 253-262.

McDermott MP, Erb HN, Natzke RP et al. (1983) Cost benefit analysis of lactation therapy with somatic cell counts as indications for treatment. J Dairy Sci 66, 1198-1203.

McDougall S, Agnew KE, Cursons R et al. (2007) Parenteral treatment of clinical mastitis with tylosin base or penethamate hydriodide in dairy cattle. J Dairy Sci 90, 779-789.

Mitchell JM, Griffiths MW, McEwen SA et al. (1998) Antimicrobial drug residues in milk and meat: causes, concerns, prevalence, regulations, tests and test performance. J Food Protect 61, 742-756.

Moretain JP, Boisseau J (1989) Excretion of penicillins and cephalexin in bovine milk following intramammary administration. Food Add Contamin 6, 79-90.

OIE (2008) Guidelines on the responsible and prudent use of antimicrobial agents in veterinary medicine. [Online] 
Available from: <http://www.oie.int/eng/normes/Mcode/ en_chapitre_1.6.7.htm> [Accessed September 25 2008].

Oliver SP, Almeida RA, Gillespie BE et al. (2004) Extended ceftiofur therapy for treatment of experimentally-induced Streptococcus uberis mastitis in lactating dairy cattle. J Dairy Sci 87, 3322-3329.

Olsen JE, Christensen H and Aarestrup FM (2006) Diversity and evolution of blaZ from Staphylococcus aureus and coagulase-negative staphylococci. J Antimicrob Chemother 57, 450-460.

Owens WE, Nickerson SC and Ray CH (1999) Efficacy of parenterally or intramammarily administered tilmicosin or ceftiofur against Staphylococcus aureus mastitis during lactation. J Dairy Sci 82, 645-647.

Passantino A (2007) Ethical aspects for veterinarians regarding antimicrobial drug use in Italy. Int J Antimicrob Agents 29, 240-244.

Pitkälä A, Haveri M, Pyörälä S et al. (2004) Bovine mastitis in Finland 2001 - prevalence, distribution of bacteria and antimicrobial resistance. J Dairy Sci 87, 2433-2441.

Poutrel B, Stegemann MR, Roy O et al. (2008) Evaluation of the efficacy of systemic danofloxacin in the treatment of induced acute Escherichia coli bovine mastitis. Journal of Dairy Research 75, 310-318.

Pyörälä S, Kaartinen L, Käck H et al. (1994a) Efficacy of Two Therapy Regimes for Treatment of Experimentally Induced Escherichia coli Mastitis in the Bovine. J Dairy Sci 77, 453-461.

Pyörälä S, Manner E, Kesti E et al. (1994b) Local tissue damage in cows after intramuscular injections of eight different antimicrobial agents. Brief communication. Acta vet Scand 35, 107-110.

Pyörälä S, Pyörälä E (1998) Efficacy of parenteral administration of three antimicrobial agents in treatment of clinical mastitis in lactating cows: 487 cases (19891995). J Am Vet Med Assoc 212, 407-412.

Rantala M, Kaartinen L, Välimäki E et al. (2002) Efficacy and pharmacokinetics of enrofloxacin and flunixin meglumine for treatment of cows with experimentally induced Escherichia coli mastitis. J vet Pharmacol Therap 25, 251-258.

Raymond MJ, Wohlre RD and Call DR (2006) Assessment and Promotion of Judicious Antibiotic Use on Dairy Farms in Washington State. J Dairy Sci 89, 3228-3240.

Sanders P, Moulin G, Guillot P et al. (1992) Pharmacokinetics of spiramycin after intravenous, intramuscular and subcutaneous administration in lactating cows. J vet Pharmacol Therap 15, 53-61.

Sawant AA, Sordillo LM and Jayarao BM (2005) A survey on antibiotic usage in dairy herds in Pennsylvania. J Dairy Sci 88, 2991-2999.

Sawant AA, Gillespie BE, Oliver SP (2009) Antimicrobial susceptibility of coagulase-negative Staphylococcus species isolated from bovine milk. Vet Microb 134, 73-81.

Shephard RW, Malmo J and Pfeiffer DU (2000) A clinical trial to evaluate the effectiveness of antibiotic treatment of lactating cows with high somatic cell counts in their milk. Austr Vet J 78, 763-768.

Shpigel NY, Levin D, Winkler M et al (1997) Efficacy of cefquinome for treatment of cows with mastitis experimentally induced using Escherichia coli. J Dairy Sci
80, 318-323.

Sol J, Sampimon OC, Barkema HW et al. (2000) Factors associated with cure after therapy of clinical mastitis caused by Staphylococcus aureus. J Dairy Sci 83, 278284.

Taponen S, Dredge K, Henriksson B et al. (2002) Efficacy of intramammary treatment with procaine penicillin $\mathrm{G}$ vs. procaine penicillin plus neomycin in bovine clinical mastitis caused by penicillin-susceptible, gram-positive bacteria - a double blind field study. J vet Pharm Therap 26, 193-198.

Taponen S, Jantunen A, Pyörälä E et al. (2003) Efficacy of targeted five day parenteral and intramammary treatment of clinical Staphylococcus aureus mastitis caused by penicillin-susceptible or penicillin-resistant bacterial isolate. Acta vet Scand 44, 53-62.

Ullberg S, Hansson E and Funke H (1958) Distribution of penicillin in mastitic udders following intramammary injection - an autoradiographic study. Am J Vet Res 19, 84-92.

Waage S (1997) Comparison of two regimens for the treatment of clinical bovine mastitis caused by bacteria sensitive to penicillin. Vet Rec 141, 616-620.

Wagner S, Erskine R (2006) Antimicrobial drug use in bovine mastitis. In: Antimicrobial Therapy in Veterinary Medicine 4th edn). Giguère S, Prescott JD, Baggot RD et al. (eds). Oxford, Blackwell.

Wenz JR, Barrington GM, Garry FB et al. (2001) Bacteraemia associated with naturally occurring acute coliform mastitis in dairy cows. J Am Vet Med Assoc 219, 976981. Whittem T, Hanlon D (1997) Dihydrostreptomycin or streptomycin in combination with penicillin in dairy cattle therapeutics: a review and re-analysis of published data, Part 1: Clinical pharmacology. New Zealand Vet J 45, 178-184.

Wilson DJ, Gonzalez RN, Case KL et al. (1999) Comparison of seven antibiotic treatments with no treatment for bacteriological efficacy against bovine mastitis pathogens. J Dairy Sci 82, 1664-1670.

Ziv G (1980) Drug selection and use in mastitis: systemic vs. local therapy. J Am Vet Med Assoc 176, 1109-1115.

Ziv G, Storper M (1985) Intramuscular treatment of subclinical staphylococcal mastitis in lactating cows with penicillin G, methicillin and their esters. J vet Pharmacol Therap 8, 276-283. 